Aim of the study: To determine whether the expression of HER-3 influences the survival of HER-2 positive patients with breast cancer (BC).

Material and methods: In the present work, the expression of HER-3 in a group of 35 HER-2 positive patients with BC was studied by performing immunohistochemistry $(\mathrm{IHC})$ in formalin-fixed paraffin embedded tissues.

Results: Higher HER-3 status if estimated by $\mathrm{IHC}$ correlated significantly with older age of the patients. HER-3 expression did not correlate with estrogen or progesterone receptor status, $\mathrm{pT}$ or $\mathrm{pN}$. There was also no significant difference in disease-free or overall survival (DFS and OS) between groups with different HER-3 expression, although some tendencies were seen as HER-3 expression in over $50 \%$ of cells was a factor of worse 5- and 10-year survival.

Conclusions: Further studies should be performed on a larger group of patients to confirm the prognostic role of HER-3 status determined by $\mathrm{IHC}$ in $\mathrm{BC}$.

Key words: breast cancer, HER-2, HER-3, immunohistochemistry, prognostic factor.

Contemp Oncol (Pozn) 2013; 17 (5): 446-449 DOI: $10.5114 /$ wo.2013.38564

\section{HER-3 expression in HER-2-amplified breast carcinoma}

\author{
Jacek Czopek ${ }^{1}$ Janusz Pawlęga ${ }^{2}$, Kamil Fijorek ${ }^{3}$, Mirosława Püsküllüoğlu², \\ Paweł Różanowski ${ }^{4}$, Krzysztof Okoń ${ }^{1}$
}

1Department of Pathomorphology, Jagiellonian University, Medical College, Krakow, Poland

2Department of Oncology, Jagiellonian University, Medical College, Krakow, Poland ${ }^{3}$ Department of Statistics, Krakow University of Economics, Krakow, Poland

4"Kopernik" Oncology Center, Olsztyn, Poland

\section{Introduction}

Despite the decline in breast cancer (BC) mortality in Europe, this neoplasm remains the main cause of death worldwide among women with cancer and its incidence is increasing. In the last 20 years several prognostic factors have been identified in BC. Among these, were steroid receptors (SR), such as estrogen (ER) and progesterone (PR) receptors, as well as human epidermal growth factor receptor-2 (HER-2), which have a special significance. In fact, we are currently moving from a purely morphological to a molecular cancer classification, and SR-positive, HER-2 positive and double-negative cancers constitute a surrogate of molecular grouping [1-3]. HER-2 positive BCs are regarded as aggressive, poorly differentiated tumors. However, they can usually be effectively treated with a targeted antibody, e.g. trastuzumab. HER-2 is a member of the epithelial growth factor receptor (EGFR) family, consisting of HER-1, HER-2, HER-3 and HER-4. If specific ligands are present, the EGFR family members dimerize, cross phosphorylize, and pass downstream signals through their intrinsic kinase activity. EGFRs are present on the surface of normal epithelial, mesenchymal and neural cells, and have been shown to be overexpressed on a number of neoplastic cells [4]. In several cancer types significant (10× up to 100×) overexpression of HERs may be observed. This leads to increased mitogenic signaling [5]. While overexpression of HER-2 activates one of the main mitogenic pathways, HER-3 stimulates the most important antiapoptotic pathway [6]. HER-2 overexpression or amplification is documented in $15 \%$ to $30 \%$ of invasive $B C$, while the rate for HER-3 is not well defined. Different papers report prevalence of $10 \%$ to $75 \%$ in all patients with $B C$ [7-11]. The negative prognostic value of HER-2 is well known. Relatively little attention has been paid to the prognostic significance of HER-1, HER-3 or HER-4. There are some papers suggesting increased mortality in HER-3 positive BC [7, 8, 12-14].

Currently, little is known about the significance of HER-2 and HER-3 co-expression; however, it has been proved that this co-expression is common. HER-3 creates heterodimers with other HER family members including HER-2. Blocking HER-2 or HER-3 decreases the activity of the other receptor [7, 15, 16]. HER-2/HER-3 heterodimers stimulate cancer growth through the phosphatidylinositol-3-kinase (PI3-K)/protein kinase B (AKT) pathway [7].

The aim of the present study was to investigate the prognostic significance of HER-3 expression in HER-2 positive breast cancer patients.

\section{Material and methods}

The study group consisted of 69 patients with BC treated radically at the Oncology Department of Jagiellonian University (UJ) between 1994 and 2004, and showing HER-2 3+ overexpression in immunohistochemistry (IHC). The patients were selected according to the availability of the material and its quality. The stain- 

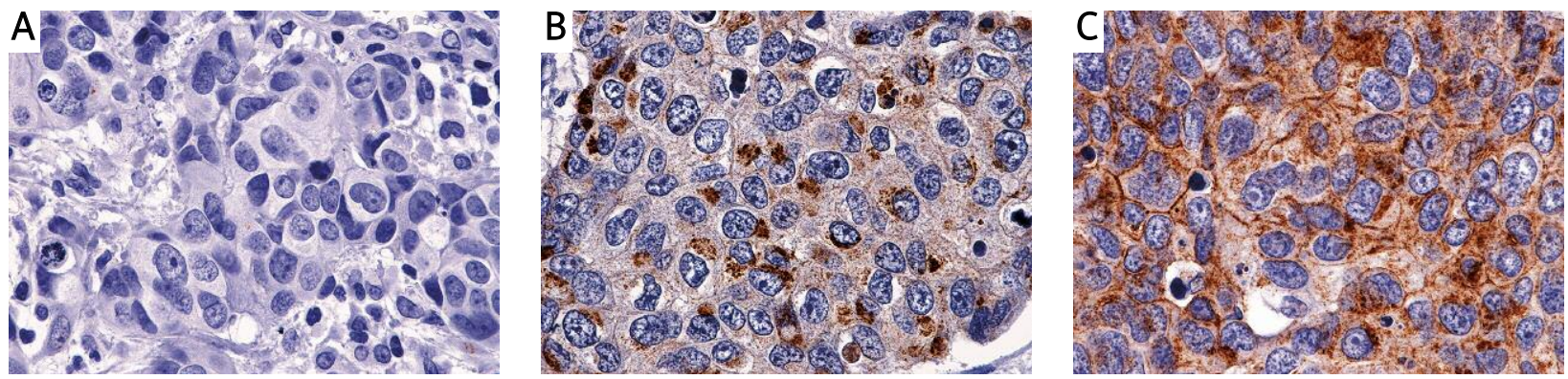

Fig. 1. HER-3 staining in HER-2 positive breast cancer tissue samples

HER-3 staining intensity classified semi-quantitatively as: (0) - no reaction, (+) - weak reaction, (++) - strong reaction (objective $60 \times$ ). A) (0) Lack of HER-3 reaction, B) (+) cytoplasmic reaction present, C) (++) cytoplasmic and cellular membrane reaction present

ings were performed on paraffin-embedded tissues from 35 patients. Tissue blocks were derived from the files of the Department of Pathomorphology UJ. The material was fixed in formalin, routinely processed, and embedded in paraffin. For each case, a single representative block was selected, and used for the IHC. From the selected blocks, $4 \mu \mathrm{m}$ thick sections were cut, and placed on SuperFrost+ (SuperFrost Inc.) coated slides. Endogenous peroxidase was blocked for 10 minutes in a $3 \% \mathrm{H}_{2} \mathrm{O}_{2}$ solution. Antigen retrieval was performed in EDTA buffer ( $\mathrm{pH} 8.0 ; 0.01 \mathrm{M}$ ) that was heated to $98^{\circ} \mathrm{C}$ for $30 \mathrm{~min}$ utes in a water bath. The slides were incubated with a primary antibody (DAKO Corp., clone DAK-H3-IC) diluted 1 : 100 for 30 minutes. The Lab Vision (Thermo Fisher Scientific Corp.) detection system with 3-amino-9-ethylcarbazole (DAKO Corp.) as chromogen was used for visualization. Mayer hematoxylin counterstaining was used.

Microscopic slides were assessed using a Nikon Eclipse 80i microscope. In every case, the cancer cells showing expression HER-3 in the cytoplasm and cellular membranes were counted, and the staining intensity was classified semi-quantitatively ("++" - strong reaction, "+" - weak reaction, "0" no reaction).

Through this process, expression of HER-3 was estimated as the percentage of HER-3 positive cells and HER-3 staining intensity [8].

The observation of the patients was conducted until June 2010. The data about clinical staging, ER, PR, local recurrence, and distant metastases were collected.

The research protocol was approved by the Jagiellonian University Ethics Committee (registry KBET/165/B/2010). The study was performed in accordance with the ethical standards laid down in the 1964 Declaration of Helsinki and its later amendments.

Baseline patients' characteristics were compared between the two groups by Mann-Whitney $U$ test or Fisher's exact test as appropriate. The Kaplan-Meier (KM) method was used to calculate the distribution of disease-free survival (DFS) and overall survival (OS). Results of KM analysis are presented as 5- and 10-year DFS and OS estimates with 95\% confidence intervals $(\mathrm{CI})$. The impact of quantitatively measured HER-3 (i.e. percentage of positive cells) on DFS and OS was assessed by hazard ratios (HR), with 95\% confidence intervals, resulting from the Cox proportional hazard regression model. A $p$-value $<0.05$ was considered significant. Statistical analysis was performed with R 2.13 software.

\section{Results}

Exemplary HER-3 stainings in HER-2 positive BC tissue samples are presented in Fig. 1A-C.

The basic characteristics of patients in relation to HER-3 status is shown in Table 1. Median age of all 35 patients was 54.4 (interquartile range 48.4-63.5, range 31-86). In the current study the frequency of combined overexpression of both HER-2 and HER-3 was 45.7\%. Patients with both HER-2 and HER-3 overexpression were significantly older than patients with HER-3 negative status. There were no differences in terms of tumor size or lymph nodes involved between the two groups. Also, no statistically significant correlation was found for ER or PR.

In Table 2, survival in relation to HER-2 and HER-3 status is shown. The 5- or 10-year OS was not dependent on HER-3 receptor status; however, 10-year survival suggests a weaker discriminative power of HER-3 qualitative assessment. A stronger suggestion, although, again, not statistically significant, arises from the analysis of DFS (Table 3). For OS HR for every $25 \%$ increase in HER-3 positive cells assessment is established as 1.233 (95\% Cl: 0.621-2.446), and for DFS as 1.064 (95\% Cl: 0.711-1.593).

\section{Discussion}

Theoretically, combined HER-2 and HER-3 expression should worsen the prognosis in comparison to HER-2

Table 1. Characteristics of patients treated for breast cancer between 1994 and 2004 in relation to HER-2 and HER-3 status

\begin{tabular}{|lccc} 
Feature & $\begin{array}{c}\text { HER-2 positive } \\
\text { and HER-3 } \\
\text { negative status* } \\
(N=19)\end{array}$ & $\begin{array}{c}\text { HER-2 and HER-3 } \\
\text { positive status** } \\
(N=16)\end{array}$ & $p$ value \\
\hline Age (years)** & $\begin{array}{c}\text { 48.9 (44.9-56.7) } \\
\text { pT1 }\end{array}$ & $61.3(52.7-70.3)$ & 0.008 \\
\hline pT2-4 & $14(73.7 \%)$ & $11(68.7 \%)$ & $>0.05$ \\
pN0 & $5(26.3 \%)$ & $5(31.2 \%)$ & $>0.05$ \\
pN1-3 & $10(52.7 \%)$ & $8(50.0 \%)$ & $>0.05$ \\
\hline ER $(+)$ & $9(56.3 \%)$ & $8(50 \%)$ & $>0.05$ \\
\hline PR $(+)$ & $9(47 \%)$ & $12(75 \%)$ & $>0.05$ \\
\hline
\end{tabular}

*HER-3 percentage of positive cells $0-50 \%$ **HER-3 percentage of positive cells $>50 \%$ ${ }_{* * *}$ Median (1st-3rd quartile) 
Table 2. Relationship of HER-3 expression with patients' overall survival in breast cancer patients (HER-2 positive)

\begin{tabular}{|c|c|c|c|c|}
\hline \multirow[t]{2}{*}{ Survival } & \multicolumn{2}{|c|}{ HER-3 percentage of positive cells } & \multicolumn{2}{|c|}{ HER-3 signal strength } \\
\hline & $0-50 \%$ & $>50 \%$ & $0 /+$ & ++ \\
\hline 5 years & $89 \%(0.76-1.00)^{\star}$ & $81 \%(0.64-1.00)$ & $88 \%(0.73-1.00)$ & $83 \%(0.68-1.00)$ \\
\hline 10 years & $89 \%(0.76-1.00)$ & $81 \%(0.64-1.00)$ & $88 \%(0.73-1.00)$ & $83 \%(0.68-1.00)$ \\
\hline
\end{tabular}

*95\% confidence interval

Table 3. Relationship of HER-3 expression with disease-free survival in breast cancer patients (HER-2 positive)

\begin{tabular}{|c|c|c|c|c|}
\hline \multirow[t]{2}{*}{ Survival } & \multicolumn{2}{|c|}{ HER-3 percentage of positive cells } & \multicolumn{2}{|c|}{ HER-3 signal strength } \\
\hline & $0-50 \%$ & $>50 \%$ & $0 /+$ & ++ \\
\hline 5 years & $74 \%(0.55-1.00)^{*}$ & $65 \%(0.44-0.95)$ & $78 \%(0.59-1.00)$ & $63 \%(0.43-0.92)$ \\
\hline 10 years & $45 \%(0.21-0.97)$ & $36 \%(0.16-0.80)$ & $34 \%(0.14-0.83)$ & $55 \%(0.35-0.87)$ \\
\hline
\end{tabular}

*95\% confidence interval

expression alone. Such a phenomenon, although not statistically significant, may be observed in our analysis, especially when disease-free survival is considered. Lack of statistical significance may be due to the small sample size, and requires further confirmation in larger studies.

It may be assumed that combined overexpression of both HER-2 and HER-3 will require development of new therapeutic modalities with monoclonal antibodies directed against both of these receptors.

The second interesting point in our results is the difference of quantitative versus qualitative HER-3 receptor assessment. HER-3 expression in over $50 \%$ of cells was a negative prognostic factor in 5-and 10-year survival. However, the group of patients with increased staining intensity showed some improvement in survival. This anomalous result should be regarded as false positive, probably due to the small sample size.

In fact, it has already been shown by other authors that the HER-3 assessment method influences results in terms of survival analysis [8].

In the literature, a correlation between HER-3 expression and lymph node status has been suggested [17]. In our study such a link was not observed. HER-3 expression has also been correlated with positive ER and PR status [18]. Regarding the obtained results, some tendency in terms of ER, although not statistically significant, could be seen.

There are data suggesting positive [19], and negative HER-3 prognostic value [9, 20]. In a study with more than 200 breast cancer tissues, overexpression of HER-3 reduced patients' survival [17]. This correlation was also seen in some studies at the RNA level, although the clinical parameters are usually correlated with the expression of HER family members at the protein level $[7,17]$. There is also one recent paper where the negative prognostic HER-3 status value was confirmed on more than 4000 tumor samples [8]. Because of the differences between the separate studies, the comparison of the data may be difficult.

The staining pattern of HER-3 is not entirely clear according to the literature. Some investigators have reported predominant cytoplasmic HER-3 staining in esophageal [21] and ovarian [22] cancer, whereas cytoplasmic and membranous expression pattern have been reported in colorectal [23], gastric [24] and BC [9]. There is also a report of HER-3 staining restricted to the cytoplasm in laryngeal carcinoma [25].

The discrepancies may be partially explained by the difference of antibodies used for staining or method of assessment of HER-3 status. However, there are no standardized methods of HER-3 staining and scoring, and according to the manufacturer of the antibody we used (Dako Corp.), both staining patterns (cytoplasmic and membranous) may be equally regarded as positive [26].

In conclusion, the co-overexpression of HER-2 and HER-3 may lead to worse BC patients' survival. However, the sample size in the current study was probably too small. Thus, it should be confirmed in a larger population. Also, the standardization of the assessment method is essential. Further research is necessary to answer additional questions, e.g. if the expression of HER-3 may change in the course of the disease, as this type of switch is observed for HER-2 [27]. The studies concerning possible prognostic and predictive factors in $\mathrm{BC}$ bring us closer to understanding the mechanisms of oncogenesis, and enhance the possibility of more adequate patients' treatment [28].

The authors declare no conflict of interests.

This study was supported by a research grant from the Jagiellonian University Medical College (K/2DS/002316).

\section{References}

1. Bosetti C, Bertuccio P, Levi F, Chatenoud L, Negri E, La Vecchia C. The decline in breast cancer mortality in Europe: an update (to 2009). Breast 2012; 21: 77-82

2. Soerjomataram I, Louwman MW, Ribot JG, Roukema JA, Coebergh JW. An overview of prognostic factors for long-term survivors of breast cancer. Breast Cancer Res Treat 2008; 107: 309-30.

3. Goldhirsch A, Wood WC, Coates AS, Gelber RD, Thürlimann B, Senn HJ. Strategies for subtypes - dealing with the diversity of breast cancer: highlights of the St. Gallen International Expert Consensus on 
the Primary Therapy of Early Breast Cancer 2011. Ann Oncol 2011; 22: $1736-47$

4. Mendelsohn J, Baselga J. The EGF receptor family as targets for cancer therapy. Oncogene 2000; 19: 6550-65.

5. Arteaga CL. Overview of epidermal growth factor receptor biology and its role as a therapeutic target in human neoplasia. Semin Onco 2002; 29: 3-9.

6. Lewis TS, Shapiro PS, Ahn NG. Signal transduction through MAP kinase cascades. Adv Cancer Res 1998; 74: 49-139.

7. Koutras AK, Evans TR. The epidermal growth factor receptor family in breast cancer. Onco Targets Ther 2008; 1: 5-19.

8. Chiu CG, Masoudi H, Leung S, Voduc DK, Gilks B, Huntsman DG, Wiseman SM. HER-3 overexpression is prognostic of reduced breast cancer survival: a study of 4046 patients. Ann Surg 2010; 251: 1107-16.

9. Sassen A, Rochon J, Wild P, Hartmann A, Hofstaedter F, Schwarz S, Brockhoff G. Cytogenetic analysis of HER1/EGFR, HER2, HER3 and HER4 in 278 breast cancer patients Breast Cancer Res 2008; 10: R2.

10. Naidu R, Yadav M, Nair S, Kutty MK. Expression of c-erbB3 protein in primary breast carcinomas. Br J Cancer 1998; 78: 1385-90.

11. Travis A, Pinder SE, Robertson JF, et al. C-erbB-3 in human breast carcinoma: expression and relation to prognosis and established prognostic indicators. Br J Cancer 1996; 74: 229-233.

12. Yao E, Zhou W, Lee-Hoeflich ST, et al. Suppression of HER2/HER3-mediated growth of breast cancer cells with combinations of GDC-0941 $\mathrm{PI} 3 \mathrm{~K}$ inhibitor, trastuzumab, and pertuzumab. Clin Cancer Res 2009; 15: 4147-56.

13. Lee-Hoeflich ST, Crocker L, Yao E, Pham T, Munroe X, Hoeflich KP, Sliwkowski MX, Stern HM. A central role for HER3 in HER2-amplified breast cancer: implications for targeted therapy. Cancer Res 2008; 68: 5878-87.

14. Wiseman SM, Makretsov N, Nielsen TO, et al. Coexpression of the type 1 growth factor receptor family members HER-1, HER-2, and HER-3 has a synergistic negative prognostic effect on breast carcinoma survival. Cancer 2005; 103: 1770-1777.

15. Neve RM, Sutterlüty H, Pullen N, Lane HA, Daly JM, Krek W, Hynes NE. Effects of oncogenic ErbB2 on G1 cell cycle regulators in breast tumour cells. Oncogene 2000; 19: 1647-56.

16. Liu B, Ordonez-Ercan D, Fan Z, Edgerton SM, Yang X, Thor AD. Downregulation of erbB3 abrogates erbB2-mediated tamoxifen resistance in breast cancer cells. Int J Cancer 2007; 120: 1874-82.

17. Bièche I, Onody P, Tozlu S, Driouch K, Vidaud M, Lidereau R. Prognostic value of ERBB family mRNA expression in breast carcinomas. Int J Cancer 2003; 106: 758-765.

18. Lee Y, Cho S, Seo JH, Shin BK, Kim HK, Kim I, Kim A. Correlated expression of erbB-3 with hormone receptor expression and favorable clinical outcome in invasive ductal carcinomas of the breast. Am J Clin Pathol 2007; 128: 1041-9.

19. Quinn CM, Ostrowski JL, Lane SA, Loney DP, Teasdale J, Benson FA. c-erbB-3 protein expression in human breast cancer: comparison with other tumour variables and survival. Histopathology 1994; 25 247-52.

20. Witton CJ, Reeves JR, Going JJ, Cooke TG, Bartlett JM. Expression of the HER1-4 family of receptor tyrosine kinases in breast cancer. J Pathol 2003; 200: 290-7.

21. Wei Q, Chen L, Sheng L, Nordgren H, Wester K, Carlsson J. EGFR, HER2 and HER3 expression in esophageal primary tumours and corresponding metastases. Int J Oncol 2007; 31: 493-9.

22. Tanner B, Hasenclever D, Stern K, et al. ErbB-3 predicts survival in ovarian cancer. J Clin Oncol 2006; 24: 4317-23.

23. Kountourakis P, Pavlakis K, Psyrri A, Rontogianni D, Xiros N, Patsouris E, Pectasides D, Economopoulos T. Prognostic significance of HER3 and HER4 protein expression in colorectal adenocarcinomas. BMC Cancer 2006; 6: 46.

24. Hayashi M, Inokuchi M, Takagi Y, Yamada H, Kojima K, Kumagai J, Kawano T, Sugihara K. High expression of HER3 is associated with a decreased survival in gastric cancer. Clin Cancer Res 2008; 14: 7843-9.

25. Wei Q, Sheng L, Shui Y, Hu Q, Nordgren H, Carlsson J. EGFR, HER2, and HER3 expression in laryngeal primary tumors and corresponding metastases. Ann Surg Oncol 2008; 15: 1193-201.
26. Dako Corp. HER-3 Clone DAK-H3-IC PDF Specification Sheet: http://www.dako.com/pl/download.pdf?objectid=114114001 (last access: 30.04.2013)

27. Ābolin,̌̌ A, Vanags A, Trofimovičs G, Miklaševičs E, Gardovskis J, Štrumfa I. Molecular subtype shift in breast cancer upon trastuzumab treatment: a case report. Pol J Pathol 2011; 1: 65-8.

28. Ziaja-Sołtys M, Rzymowska J. Analiza ekspresji wybranych genów kodujących aktywatorowe czynniki transkrypcyjne w komórkach przewodowego raka piersi in vitro poddanych działaniu paklitakselu. Contemp Oncol (Pozn) 2011; 15: 69-73.

\section{Address for correspondence}

\section{Prof. Janusz Pawlęga}

Department of Oncology

Jagiellonian University, Medical College

Grzegorzecka 20

31-531 Krakow, Poland

e-mail: japa46@op.pl

Submitted: 4.02.2013

Accepted: $\quad 27.05 .2013$ 